\title{
高齢者の進行非小細胞肺癌に対する化学療法
}

\author{
梁 英富 1 外山勝弘 1 - 磯部和順 $1 \cdot$ 杉野圭史 1 佐野 剛 1 ・ \\ 山田浩之 ${ }^{1} \cdot$ 廣井眞弓 $1 \cdot$ 北條貴子 $1 \cdot$ 木村一博 1
}

要旨一一目的. 高齢者の進行非小細胞肺癌に対する化学療法の安全性と有用性について検討した. 対象・方法. 最近 5 年間に化学療法を施行した非小細胞肺癌 192 例を対象として, 70 歳以上の高齢者群 49 例と 70 歳未満の非高齢者群 143 例の 2 群に分けて患者背景, 治療内容, 血液毒性, 治療効果, 生存期間を比較検討した. 結果. 高齢者群では performance status:0〜 1 と臨床病期 III 期の比較的条件の良い症例が多くを占めていた. 高齢者群の $71 \%$ cisplatin (CDDP)が併用されており, 治療内容, 血液毒性, 抗腫瘍効果については両群間に有意差を認めなかった. しかし，75 歳以上では半数の症例で投与量が減量され, 投与回数も少ない傾向がみられた.さらに CDDP 併用群では Grade 3 以上 の血液毒性の発現率が $77 \%$ と非常に高度であった. 生存期間中央值は高齢者群 32 週に対し非高齢者群 24 週と高齢者 群で有意に優れていたが, 減量投与された高齢者群の奏効率は低く予後も不良であった。 また, 多変量解析ではPS, 臨床病期, 組織型, 抗癌剂投与量が有意な予後因子であり, 年齢は有意な子後因子ではなかった. 結論. 高齢者でも選 択された症例に対しては非高齢者と同等の毒性と治療成績が得られ, 高齢者に対する化学療法の有用性が示唆された. しかし，75 歳以上の症例では CDDP を含まない高齢者レジメンが必要であると考えられた.（肺癌. 2002;42:175-179） 索引用語 ——肺癌, 高齢者, 化学療法

\section{Chemotherapy for Elderly Patients With Advanced Non-small Cell Lung Cancer}

\author{
Hidetomi Ryo ${ }^{1}$; Katsuhiro Toyama ${ }^{1}$; Kazutoshi Isobe ${ }^{1}$; Keishi Sugino ${ }^{1}$; Gou Sano ${ }^{1}$; \\ Hiroyuki Yamada ${ }^{1}$; Mayumi Hiroi ${ }^{1}$; Takako Hojyo ${ }^{1}$; Kazuhiro Kimura ${ }^{1}$
}

\begin{abstract}
Objective. To evaluate the safety and the usefulness of chemotherapy for elderly patients with advanced non-small cell lung cancer (NSCLC), retrospective analysis was performed. Patients and Methods. A total of 192 patients who received chemotherapy were divided into two groups: the elderly group ( $\geq 70$ years old, 49 patients), and the non-elderly group ( $<70$ years old, 143 patients). Hematologic toxicity, non-hematologic toxicity, tumor response and overall survival were analyzed. Results. In the elderly group, most patients had better prognostic factors; performance status (PS) 0-1, and stageIII. A regimen including cisplatin (CDDP) was administered in $71 \%$ of patients in the elderly group. No significant differences in treatment, hematologic toxicity and tumor response were observed between the two groups. In patients who received CDDP in the elderly group, the incidence of Grade 3 or more severe hematologic toxicities was significantly higher than that of the non-elderly group, $77 \%$ and $43 \%$, respectivily. The survival curve of the elderly group was significantly $(p<0.05)$ more prolonged than that of the non-elderly group. Using Cox proportional hazards model, it was found that PS, clinical stage, histology and treatment dose were significant prognostic factors, but age was not a significant prognostic factor. Conclusion. Selected elderly patients with good PS and no combined organ dysfunctions are candidates for chemotherapy. Since CDDP might induce severe side effects, a regimen without CDDP should be selected for patients over 75 years old. (JJLC. 2002;42:175-179)
\end{abstract}

\footnotetext{
1 東邦大学第 1 内科.

別刷請求先：梁 英富, 東邦大学第 1 内科, $\% 143-8541$ 東京 都大田区大森西 6-11-1.

1First Department of Internal Medicine, Toho University, Japan.
}

Reprints: Hidetomi Ryo, First Department of Internal Medicine, Toho University, 6-11-1 Omorinishi, Ota-ku, Tokyo 143-8541, Japan.

Received November 16, 2001; accepted March 13, 2002.

(C) 2002 The Japan Lung Cancer Society 
KEY WORDS — Lung cancer, Elderly, Chemotherapy

\section{緒 言}

世界的な動向として肺癌は増加しており，また同時に 高齢者肺癌の割合は増加傾向にある.1 しかし, 高齢者は 合併症の頻度の高さや主要藏器機能の低下と全身状態, 毒性の発現などが問題となることから，これまでは非小 細胞肺癌においては積極的に化学療法が行われることは 少なかった。ところが近年，高歯者に対する肺癌化学療 法の位置付けは変化してきており，抗癌剤治療により延 命効果および quality of life (QOL) の改善が得られること が報告2-6され, 高齢者に対してもより積極的に化学療法 が行われるようになってきた。しかし，高齢者に対して は未だ適切な治療方法が確立されておらず，治療の選択 基準やレジメンなどといった問題点が多いことから推奨 されるべき治療方法の研究は重要課題であると思われ る.そこでわれわれは高齢者の非小細胞肺癌に対する化 学療法の安全性と有用性について非高齢者と比較検討 し,さらに化学療法の意義と問題点についても検討した.

\section{対象および方法}

1996 年 1 月から 2000 年 12 月までの 5 年間に当科で 化学療法を施行した非小細胞肺癌症例 192 例を対象とし て, 70 歳以上の高歯令者群 49 例と 70 歳未満の非高齢者群 143 例の 2 群に分け, 患者背景, 治療内容, 血液毒性, 抗 腫瘍効果, 生存期間について比較し高齢者に対する化学 療法の安全性と有用性について検討した。また化学療法 の臨床試験では 75 歳で区切っていることが多いことか ら，高齢者群を 75 歳未満（37 例）と以上（12 例）に分 けて同様の検討も行った。さらに Cox の比例ハザードモ デルを用いた多変量解析を行い子後因子についても検討 した. なお, 当院では化学療法の適格基準を 75 歳未満と していることから原則として 75 歳未満に対しては 70 歳 以下と同様に治療が施行され，75 歳以上の症例に対する 治療方法に関しては主治医の判断に委ねられている。生 存率は Kaplan-Meier 法で計算し, 各群間の有意差検定は Generalized Wilcoxon test を用いた. 統計学的解析は $\chi^{2}$ 検定， student $t$ test を用い， $\mathrm{p}<0.05$ を有意水準とした。

\section{結 果}

\section{1. 患者背景}

高齢者群 49 例の患者背景を Table 1 に示す．男性 39 例，女性 10 例，平均年齢は 74 歳（70 83 歳）で, 75 歳未満が最も多く 37 例 $(75 \%)$ を占めた。 performance status (PS) は PS:0〜1 が 37 例 (75\%)，2〜4 が 12 例で, 組織型は腺癌 25 例, 扁平上皮癌 21 例, 大細胞癌 3 例,
Table 1. Patient characteristics

\begin{tabular}{lcc}
\hline & Age $\geq 70$ & Age $<70$ \\
\hline No. of cases & 49 & 143 \\
Median age (range) & $74(70-83)$ & $64(19-69)$ \\
Sex & & \\
$\quad$ Male/Female & $39 / 10$ & $107 / 36$ \\
PS & & \\
$\quad 0-1$ & 37 & 85 \\
$2-4$ & 12 & 58 \\
Clinical stage & & \\
$\quad$ III / I & $23 / 26$ & $60 / 83$ \\
Histology & & \\
$\quad$ Adenocarcinoma & 25 & 104 \\
$\quad$ Squamous cell carcinoma & 21 & 29 \\
Large cell carcinoma & 3 & 8 \\
\hline
\end{tabular}

臨床病期は III 期 23 例, IV 期 26 例であった. 性別, PS, 臨床病期，組織型において高齢者群と非高齢者群の間に 有意差は認められないものの, 高齢者群では PS:0〜1 臨床病期 III 期症例の占める割合が多かった。一方，同時 期に当院に入院した 70 歳以上の進行非小細胞肺癌症例 は 74 例でそのうちの 25 例 $(34 \%)$ に対しては化学療法 が施行されなかった。その理由としては，1）年齢（75 歳以上）だけの理由で除外されたもの 6 例，2）PS 不良 (PS:1〜4) または主要臓器機能の低下 10 例，3）転移や胸 水貯留などの理由で長期生存が望めないと判断されたも の 5 例，4）本人または家族の治療拒否 4 例であった。本 来であれば化学療法の除外基準とならない症例も多く含 まれており，主治医の判断で胸水コントロールや姑息的 な放射線療法を含む支持療法のみが実施されていた。そ してその内訳を年齢別にみると 75 歳以上の症例がその 内の 20 例 $(80 \%)$ を占めていた.

\section{2. 治療内容}

高歯令者群の治療内容を Table 2 に示す. 49 例のうち 35 例 $(71 \%)$ に cisplatin (CDDP) を含む併用化学療法が施 行されていた。また，臨床病期 III 期 23 例のうち 16 例 (70\%)に胸部放射線治療が併用されていた。全体の平均 投与回数は 3.5 コースで，15例（30\%）では高齢やPS 不良の理由から投与量が標準量の 50 〜 $80 \%$ に減量され ていた。一方，非高齢者群との比較では CDDP の併用率 (非高齢者群 $77 \%$ )，胸部放射線治療の併用率 (非高齢者 群 83\%）に有意差は認められなかった。さらに高齢者群 を 75 歳で区分して検討したところ, CDDP の併用率と胸 部放射線療法の併用率はほぼ同等であったが，75 歳以上 では 12 例中 6 例で投与量が減量されており, 平均投与回 数も2 コースと少ない傾向がみられた. 
Table 2. Treatment of the two groups

\begin{tabular}{lcccc}
\hline & \multicolumn{3}{c}{ Age $\geq 70$} & Age $<70(\mathrm{n}=143)$ \\
\cline { 2 - 4 } & $70-74(\mathrm{n}=37)$ & $\geq 75(\mathrm{n}=12)$ & Total $(\mathrm{n}=49)$ & 77 \\
\hline Cisplatin-based regimen (\%) & 70 & 75 & 71 & 83 \\
Chemotherapy + Radiotherapy (\%) & 71 & 67 & 70 & 92 \\
100\% Dose (\%) & 76 & 50 & 70 & 12 \\
Treatment cycle(\%) & & & & 27 \\
$\quad$ cycle & 21 & 42 & 39 & 66 \\
2 cycles & 41 & 33 & 34 & \\
$\geq 3$ cycles & 38 & 25 & & \\
\hline
\end{tabular}

Table 3. Hematological toxicity

\begin{tabular}{lccccc}
\hline & \multicolumn{3}{c}{ Age $\geq 70(\%)$} & \multirow{2}{*}{ Age $<70(\%)$} & p-value \\
\cline { 2 - 4 } & $70-74$ & $\geq 75$ & Total & & \\
\hline Leukopenia(G3/4) & 35 & 50 & 39 & 30 & NS \\
Neutropenia (G3/4) & 38 & 50 & 43 & 35 & NS \\
Anemia (G3/4) & 24 & 25 & 24 & 20 & NS \\
Thrombocytopenia (G3/4) & 19 & 0.8 & 21 & 11 & NS \\
Total (G3/4) & 43 & 67 & 51 & 41 & NS \\
\hline
\end{tabular}

p-value: over 70 years vs under 70 years old.

\section{3. 血液毒性}

血液毒性を Table 3 に示す. Grade 3 以上の血液毒性の 発現頻度は高齢者群 $51 \%$ vs 非高齢者群 $41 \%$ で，白血球 減少 $(39 \%$ vs $30 \%)$ ，好中球減少 $(43 \%$ vs $35 \%)$ ，貧血 $(24 \%$ vs $20 \%) ，$ 血小板減少 ( $21 \%$ vs $11 \%)$ であった。両 群間で発現頻度に有意差は認められないものの高齢者群 でやや高い傾向がみられた。 また, CDDP 併用群での同様 の発現頻度は高齢者群 $54 \%$, 非高齢者群 $43 \%$ であった. 高齢者群を 75 歳で区分して同様の検討をしたところ, 75 歳未満の発現頻度が $43 \%$ と非高齢者群と同等であった のに対し， 75 歳以上では $67 \%$ と高く, とりわけ CDDP 併用群では $77 \%$ と非常に高頻度であった。

\section{4. 抗腫瘍効果}

抗腫瘍効果を Table 4 に示す. 奏効率は高歯令者群 $34 \%$, 非高齢者群 $30 \%$ で有意差は認められなかった。また， 75 歳以上の肺癌患者 12 例の奏功率は $33 \%$ であったが, 減 量投与された高齢者群 15 例の奏功率は $20 \%$ と低い傾向 が認められた。

\section{5. 生存期間}

生存曲線を Figure 1 に示す. 生存期間中央值は高齢者 群 32 週，非高齢者群 24 週で高齢者群では有意に生存期 間が優れていた。しかし，1 年生存率は高齢者群 $45.8 \%$, 非高齢者群 $50.6 \%$ で差は認められなかった。また， 75 歳以上の生存期間中央值は 30 週であったが, 減量投与さ れた高齢者群の生存期間中央值は 20 週と予後不良で あった。
Table 4. Response

\begin{tabular}{lcccrcc}
\hline & CR & PR & NC & PD & Response rate (\%) & p-value \\
\hline Age $\geq 70$ & 1 & 16 & 24 & 8 & 34 & NS \\
Age $<70$ & 3 & 40 & 67 & 33 & 30 & \\
\hline
\end{tabular}

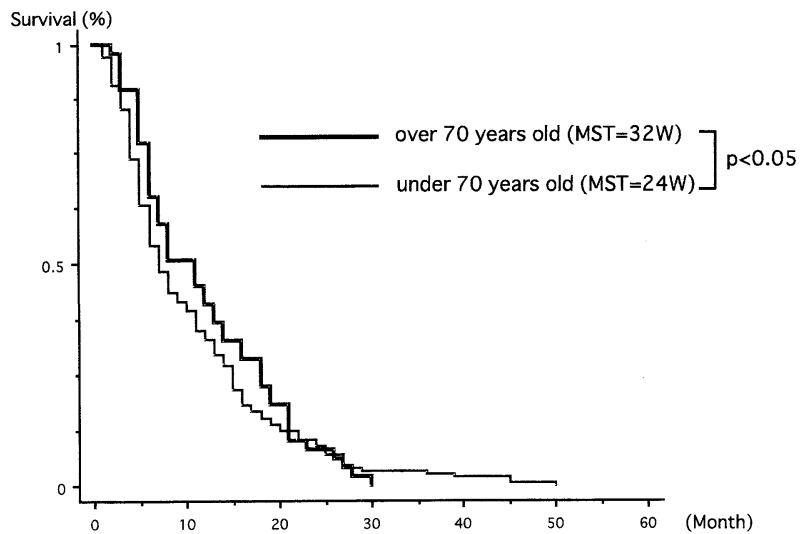

Figure 1. Survival curves accoording to age.

\section{6. 予後因子}

予後因子として，年齢，性別，PS，組織型，臨床病期， 抗癌剂投与量, 投与回数について検討した. 治療開始か らの生存率を単因子分析した結果, PS, 組織型, 臨床病 期，抗癌剂投与量，投与回数に有意差を認めた。また多 変量解析ではPS, 組織型, 臨床病期, 抗癌剂投与量に有 意差を認めたが年齢は予後因子とはならなかった (Table 
Table 5. Prognostic factors determined by multivariate analysis using Cox Proportional hazards model

\begin{tabular}{|c|c|c|c|}
\hline Factor & Hazard ratio & $95 \%$ confidence interval & $\mathrm{p}$-value \\
\hline \multicolumn{4}{|l|}{ Age } \\
\hline$\geq 70$ & 1 & & \\
\hline$<70$ & 0.862 & $0.529-1.403$ & 0.54 \\
\hline \multicolumn{4}{|l|}{ Sex } \\
\hline female & 1 & & \\
\hline male & 0.684 & $0.441-1.062$ & 0.090 \\
\hline \multicolumn{4}{|l|}{ Performance status } \\
\hline $0-1$ & 1 & & \\
\hline $2-4$ & 1.498 & $1.013-2.214$ & 0.042 \\
\hline \multicolumn{4}{|l|}{ Clinical stage } \\
\hline III & 1 & & \\
\hline IV & 1.567 & $1.179-2.084$ & 0.0020 \\
\hline \multicolumn{4}{|l|}{ Histology } \\
\hline non-adenocarcinoma & 1 & & \\
\hline adenocarcinoma & 1.478 & $1.062-2.058$ & 0.020 \\
\hline \multicolumn{4}{|l|}{ Treatment dose } \\
\hline $100 \%$ & 1 & & \\
\hline$<100 \%$ & 2.001 & $1.153-3.474$ & 0.013 \\
\hline \multicolumn{4}{|l|}{ Treatment cycle } \\
\hline$\geq 3$ & 1 & & \\
\hline $1-2$ & 0.748 & $0.492-1.139$ & 0.17 \\
\hline
\end{tabular}

5). Stepwise 法でも同様の結果が得られ，生存率への寄 与の強い順は抗癌剤投与量, 臨床病期, 組織型, PS であっ た。

\section{考 察}

進行非小細胞肺癌の化学療法としてはプラチナ製剤を 含む併用化学療法が推奨7され，わずかではあるが予後 の延長に有効であるとされている.8しかし, CDDPを中 心とした化学療法は, その有効性に比して強い毒性がみ られることから高齢者に対しては適応しづらく実施が困 難であることが多かった．近年，いくつかの新規抗癌剤 が認可され，なかでも vinorelbine 小 $^{2-4}$ や gemcitabine ${ }^{5,6}$ は 高齢者に対し忍容性が高く有用であることが報告されて いる．そこで高齢者に対する化学療法の安全性と有用性 およびその意義と問題点について retrospective に検討 した.

今回の検討では, 高齢者に対して化学療法が施行され なかった症例のほとんどが 75 歳以上であった。しかし， これらの症例の中には主治医の主観で PS が 1 2 と比 較的良くても全身状態不良と判断された症例や進行例と いう理由だけで除外された症例も多く含まれていた。そ の背景には全身状態をPS で評価することが時に困難で あること，化学療法による毒性や QOL の低下，また長期 入院による痴呆問題などが配慮されていたと思われ，高 齢者肺癌特有の治療選択の難しさが明らかになった。そ
して当施設では年齢（75 歳以上）が治療の選択基準を最 も大きく左右していたと考えられた。一方，75 歳以上の 肺癌症例に対して治療のより厳格な選択基準を満たした 症例は $29 \%$ しかなく,9 臨床試験に基づいた選択基準で も $37 \%$ に過ぎなかった10 と報告されている.これらの報 告からも 75 歳以上で化学療法の適応となるのは選択さ れた症例のみであり，今後は適応をより拡大するための 侵襲の少ない治療レジメンを検討する必要があると考え られた。

治療内容に関しては, CDDP の併用率, 胸部放射線治療 の併用率において高齢者群と非高齢者群の間に有意差は 認められなかった. Shepherd ら11 は高齢になるほど減量 投与の必要性が大きくなり，投与回数も少なくなると報 告してしているが，われわれの検討でも同様の傾向がみ られた。そして, その傾向は特に 75 歳以上の症例で顕著 であった．そこでそのような消極的治療の意義を成績の 観点から検討した. 今回の検討では，レジメンや投与量 が統一されていないため単純に比較することは困難では あるが, 自験例の減量投与された 15 例の奏効率 $20 \%$, 生 存期間中央值 20 週は高齢者に対する vinorelbine 単剤の 奏効率 $19.7 \%$, 生存期間中央值 28 週 2 や MILES の報告4 したCDDPを含まないレジメンの成績と比べても同等 以下であった。 そして多変量解析の結果でも抗癌剤投与 量は最も重要な予後因子であることが示されている。こ れらのことより消極的治療の意義については疑問であ 
り，CDDP が十分に投与できない高齢者に対しては先に 報告された新規抗癌剤の単剂投与のほうが望ましいと考 えられた。

また，高歯者に対しては強い毒性が出現することから CDDPを含むレジメンが適切であるか否かが問題とな る.これまでの報告では, CDDP による重篤な毒性はみら れなかったとする報告 12,13 が大部分であるが，75 歳以上 の高齢者に対しては CDDP を含む併用化学療法は不適 当であるとの報告 11 もる. 今回の検討では，75 歳未満 の高齢者においいて毒性が非高齢者群と同等であったこと から認容可能であり有効に投与し得ることが示唆され た。しかし，75 歳以上の高歯者においては選択条件が良 く，投与量を減量しているにもかかわらず強い血液毒性 が発現したことから毒性の観点からは CDDPは不適と 考えられた。

血液毒性に関しては, 70 歳以上では毒性の頻度が増強 されると報告14,15されている。しかし，自験例では 75 歳未満であれば毒性の発現頻度に与える影響は少なく, 75 歳以上で頻度が増強されると考えられた。

治療成績に関しては, 70 歳以上の高齢者は予後不良と する報告 16 や抗腫瘍効果，生存期間で有意差を認めない とする報告5,13 などさまざまである．自験例の検討では， 高齢者群は非高齢者群と比較して抗腫瘍効果は同等であ り，生存期間では有意に治療成績が優れていた，その理 由としては retrospective な解析のため高齢者群ではPS や臨床病期といった患者背景に selection bias がかかっ ているためと推測され，予後に対する正当な評価は困難 である.しかしながら，このことは換言すれば高齢者で も条件の良い選択された症例に対しては積極的な化学療 法の有用性が示唆されたと考える。ただし今回の検討で は 75 歳以上の症例数が 12 例と少なく高齢者群に占める 割合が小さいこと，そして 75 歳以上の肺癌患者 32 例の うち 12 例にしか化学療法が行えなかったという事実か ら，75 歳以上の肺癌患者に対する化学療法の安全性と有 用性に関する評価についてはさらに症例を集積し検討す る必要があると考えられた。

これらの結果から 75 歳未満の症例であれば非高齢者 と同様に化学療法を施行することが可能である。一方, 75 歳以上の症例においてはさらなる検討を要するが，高 齢者の特性に十分対応できる CDDP を含まない高齢者 レジメンが必要であると考えられた。

\section{REFERENCES}

1. Johnson DH. Small cell lung cancer in the elderly patient. Semin Oncol . 1997;24:484-491.

2. The Elderly Lung Cancer Vinorelbine Italian Study Group. Effects of vinorelbine on quality of life and survival of elderly patients with advanced non-small-cell lung cancer. J Natl Cancer Inst. 1999;91:66-72.

3. Buccheri G, Ferrigno D. Vinorelbine in elderly patients with inoperable nonsmall cell lung carcinoma: a phase II study. Cancer. 2000;88:2677-2685.

4. Gridelli C, Perrone F, Cigolari S, et al. The MILES (Multicener Italian Lung Cancer in the Elderly Study) phase 3 trial: gemcitabine + vinorelbine vs vinorelbine and vs gemcitabine in elderly advanced NSCLC patients. Proc ASCO. 2001;20:308a.

5. 古瀬清行. Gemcitabine Hydrochloride (Gemcitabine)の 高齢者非小細胞肺癌に対する治療成績. 癌と化学療法. 1999;26:890-897.

6. Ricci S, Antonuzzo A, Galli L, et al. Gemcitabine monotherapy in elderly patients with advanced non-small cell lung cancer: a multicenter phase II study. Lung cancer. 2000;27:75-80

7. American Society of Clinical Oncology. Clinical practice guidlines for the treatment of unresectable non-small-cell lung cancer. J Clin Oncol. 1997;15:2996-3018.

8. Non-small Cell Lung Cancer Collaborative Group. Chemotherapy in non-small cell lung cancer: a meta-analysis using updated data on individual patients from 52 randomized clinical trials. BMJ. 1995;311:899-909.

9. Oshita F, Kurata T, Kasai T, et al. Prospective evaluation of the feasibility of cisplatin-based chemotherapy for elderly lung cancer patients with normal organ functions. Jpn J Cancer Res. 1995;86:1198-1202.

10. 瀧川奈義夫, 畧川芳彦, 岸野大蔵, 他. 超高齢者非小細胞 肺癌に対する化学療法一ifosfamide と vindesine 併用療 法を中心に一。 日呼吸会誌. 2000;38:273-277.

11. Shepherd FA, Amdemichael E, Evans WK, et al. Treatment of small cell lung cancer in the elderly. $J$ Am Geriatr Soc. 1994;42:64-70.

12. Thyss A, Saudes L, Otto J, et al. Renal tolerance of cisplatin in patients more than 80 years old. J Clin Oncol. 1994;12:2121-2125.

13. Siu LL, Shepherd FA, Murray N, et al. Influence of age on the treatment of limited-stage small-cell lung cancer. $J$ Clin Oncol . 1996;14:821-828.

14. Begg CB, Carbone PP. Clinical trials and drug toxicity in the elderly. The experience of the Eastern Cooperative Oncology Group. Cancer. 1983;52:1986-1992.

15. Kubota K, Furuse K, Kawahara M, et al. Cisplatin-based combination chemotherapy for elderly patients with nonsmall-cell lung cancer. Cancer Chemother Pharmacol. 1997;40:469-474.

16. Albain KS, Crowley JJ, LeBlanc M, et al. Determinants of improved outcome in small-cell lung cancer: an analysis of the 2,580-patient Southwest Oncology Group data base. J Clin Oncol. 1990;8:1563-1574. 